P

\section{Progressive supranukleäre Blickparese}

Helga Peter

Marburg, Deutschland

\section{Definition}

Neurodegenerative Erkrankung, die zu den Parkinson-plusSyndromen zählt.

Siehe auch $\triangleright$,Parkinson-Syndrome“.

\title{
Synonyme
}

PSP 